\title{
Negative Polarity in Hindi
}

\author{
Utpal Lahiri \\ University of California at Irvine
}

\section{Introduction}

In this paper, I provide an account of Negative Polarity Items (NPIs) in Hindi. I note that NPIs in Hindi are morphologically made up of an indefinite existential or a weak predicate and a particle that means also or even. I argue that the NPI and free-choice-like behavior of these expressions comes about from the way these expressions are made up. I argue that in "positive" contexts the combination of even and a weak predicate leads to "implicature-clash", i.e., contradictory implicatures. In downward-entailing and generic contexts, there is no implicatureclash involved, hence these expressions can occur freely. Combined with the fact that indefinites in generic contexts have generic rather than existential readings explains the distribution of these expressions. This account is explanatory to the extent that instead of just stating the licensing conditions for NPIs in Hindi, this provides an explanation on independent grounds for the why the expressions in question are restricted to downward-entailing and generic and (some) modal contexts, and also provides a unified account of the NPI and free choice-behavior of these expressions. This analysis can be seen to be a development of ideas that can be found in previous work, e.g., Heim (1984), Krifka (1994), and more indirectly Kadmon and Landman (1993). This paper is a preliminary report as the discussion is largely limited to declarative contexts, and the appearance of NPI/Free choice expressions in non-declaratives like questions and imperatives is left for future work. 1

\section{The Morphology of Hindi NPIs}

Expressions that behave like NPIs in Hindi (see, e.g., Bhatia 1976) are made up of an indefinite or a weak predicate indicating small amounts and a particle bhii often described in traditional grammars as an "emphatic" marker. The following list, enumerating the NPIs and the corresponding simple existentials illustrate the point:

$\begin{array}{llll}\text { ek bhii } & \text { 'any, even one' } & \text { ek 'one' } \\ \text { koii bhii } & \text { 'anyone, any (count)' } & \text { koii } & \text { 'someone' } \\ \text { kuch bhii } & \text { 'anything, any (mass) } & \text { kuch } & \text { 'something, a little' } \\ \text { zaraa bhii } & \text { 'even a little' } & \text { zaraa 'a little' } \\ \text { kabhii bhii } & \text { 'anytime, ever' } & \text { kabhii 'sometime' } \\ \text { kahiiN2 bhii 'anywhere' } & \text { kahiiN 'somewhere' }\end{array}$

\footnotetext{
${ }^{1}$ At the time of writing of this paper it came to the author's attention that Larry Horn and YoungSuk Lee had independently arrived at an account of the English any that is very similar in essentials to the account proposed here for Hindi NPIs.

${ }^{2}$ I adopt the following conventions that deviate from the IPA for transcribing Hindi sounds, common among South Asian linguists: the symbols T, D stand for the retroflex voiceless and voiced stops respectively, the symbol $\mathrm{N}$ indicates nasalization on the preceding vowel, $\mathrm{S}$ is the alveopalatal voiceless fricative, $c, j$ are the voiceless and voiced alveopalatal affricates, $R$ is the
} 
It should be noted that the particle bhii can attach to different kinds of of phrases, in particular, it can attach to NPs (including proper names), VPs, verbs, etc. (the exact characterisation of the relevant class is an issue of Hindi syntax that is not relevant here). What is important for our purposes is that the expressions in (1) are syntactically "frozen" so to speak. Thus, from $e k$ 'one' we have the NPI $e k$ bhii 'any, even one', but the particle bhii cannot be attached to other numerals like do 'two', tiin 'three', etc. to yield *do bhii 'even two', *tiin bhii 'even three', etc., even though it can be attached to phrases containing numerals, for example, do log bhii 'even TWO ${ }^{3}$ people', tiin log bhii 'even THREE people'. This is illustrated in the following examples:

(2) do rasoiye bhii khaanaa bigaaR dete haiN two cooks emph food spoil aux. "Even two cooks will spoil the broth".

(3) * do bhii rasoiyee khaanaa bigaaR dete haiN two emph cooks food spoil aux. "Even two cooks will spoil the broth".

To summarise, despite the internal structure of these expressions, and the compositional analysis of the semantics of these expressions that will follow, these expressions have a special status syntactically, being like idiom chunks in certain respects.

\section{The "Emphatic" Particle bhii}

The particle bhii appearing in these expressions is often described as an "emphatic marker" in traditional grammars, with the exact content left unspecified. Even a cursory examination shows, however that the particle in ordinary contexts means something like the English expression also. Thus consider the following example:

(4) raam bhii aayaa

Ram emph came

(4) asserts (5a) and implicates (5b):
(5) a. Ram came
(Assertion)
b. $\exists x[x \neq R a m \wedge x$ came $]$ (Implicature)

When however the word raam is focussed, we get an additional implicature over and above (5b), viz., (5c):

$$
\begin{array}{r}
\text { c. } \forall \mathrm{x}[\mathrm{x} \text { came } \rightarrow \text { likelihood(that } \mathrm{x} \text { came) }>\text { likelihood(that Ram came) }] \\
\text { (Implicature) }
\end{array}
$$

What this shows is that the "emphatic" marker bhii is really ambiguous between the English also and even, the even-meaning showing up in focussed contexts, and 
the also-reading being prominent in non-focussed contexts. ${ }^{4}$ It is reasonable to assume then that bhii means even in focus-affected contexts, and since NPIs in Hindi are focussed, bhii in these contexts simply corresponds to the English even.

\section{The Distribution of NPIs in Hindi}

NPIs in Hindi are found in most "downward entailing" contexts in the sense of Ladusaw (1979). Unlike English, NPIs in Hindi can be subjects when the "trigger" is in the same the clause as the subject NPI. ${ }^{5}$ A detailed description of the distribution of Hindi NPIs is given below. In general, expressions like $e k$ bhii 'even one, any', zaraa bhii 'even a little' are freer in their distribution in that examples with koii bhii 'anyone', kuch bhii 'anything', etc. are slightly less preferred in certain cases where the other NPIs are allowed, but they are never completely ungrammatical. Consider the usual NPI-licensing environments oneby-one.

\subsection{Clausemate Negation}

NPIs appear freely in the semantic scope of negation, and there is no S-Structure c-command requirement on NPI-licensing as one sees in English. ${ }^{6}$ The examples below this illustrate this.

(6) a. * koii bhii aayaa anyone came

" * Anyone came"

b. koii bhii nahiiN aayaa

anyone not came

"Noone came"

c. * maiN-ne kisii-ko bhii dekhaa

I ERG anyone saw

"* I saw anyone"

d. maiN-ne kisii-ko bhii nahiiN dekhaa

I ERG anyone not saw

"I didn't see anyone"

(7) a. * ek bhii aadmii aayaa

any man came

"* Any man came"

b. ek bhii aadmii nahiiN aayaa

any man not came

"No man came"

c. * maiN-ne ek bhii aadmii dekhaa

I ERG any man saw

"* I saw any man"

d. maiN-ne ek bhii aadmii nahiiN dekhaa

I ERG any man not saw

"I didn't see any men/man"

\footnotetext{
${ }^{4}$ One could argue that bhii really means also, the extra implicature being really a contribution of focus, but I leave that issue here.

${ }^{5}$ See section 6 for a speculation on why this might be so.

${ }^{6}$ The actual requirement in English is more complex, see Uribe-Etxebarria 1995 (this volume) for examples of subject NPIs in English triggered by Negation.
} 
(8) a. * maiN-ne kuch bhii khaayaa

I ERG anything ate

"* I ate anything"

b. maiN-ne kuch bhii nahiiN khaayaa

I ERG anything not ate

"I didn't eat anything"

(9) a. * maiN-ne zaraa bhii khaanaa khaayaa

I ERG a little even food ate

"* I ate any food"

b. maiN-ne zaraa bhii khaanaa nahiiN khaayaa

I ERG a little even food not ate

"I didn't eat any food"

\subsection{Conditionals}

Like in English, and unlike languages like Japanese, Hindi NPIs are allowed in the protasis of conditionals, but not in the apodosis. This is shown in the following examples, and it holds of indicative as well as subjunctive conditionals:

(10) a. agar raam kisii-ko bhii dekhegaa to tumhen bataayegaa

if Ram anyone see-FUT then you tell-FUT

"If Ram sees anyone, he will inform you"

b. agar tum kisii-ko bhii dekhoo to mujhe bataao

if you anyone see (subj.) then me tell

"If you see anyone, inform me".

c. * agar raam aayegaa, to kuch bhii karegaa

if Ram come-FUT then anything do-FUT

"* If Ram comes, he will do anything".?

d. agar raam ek bhii kitaab paRhegaa, to use sar dard hone lagegaa

if Ram one even book read-FUT then him headache happen

"If Ram reads any book, he'll get a headache"

e. agar raam zaraa bhii paRhegaa, to use sardard hone lagegaa

if Ram a little even read-FUT then him headache happen

"If Ram reads even a little, he'll get a headache"

f. agar raam kuch bhii paRhegaa, to use sar dard hone lagegaa

if Ram anything read-FUT then him headache happen

"If Ram reads anything, he'll get a headache"

$\mathrm{g}$ * agar raam-ko sar dard hone lagegaa, to vo ek bhii kitaab paRhegaa if $\mathrm{Ram}$ headache happen then he one even book read-FUT

"* If Ram gets a headache he will read even one book"

h. * agar raam-ko sar dard hone lagegaa, to vo zaraa bhii paRhegaa

if $\operatorname{Ram}$ headache happens then he a little even read

"* If Ram gets a headache, he'll read even a little"

i. * agar raam-ko sar dard hone lagegaa, to vo kuch bhii paRhegaa

if Ram headache happens then he anything read

"* If Ram gets a headache, he'll read anything"

One can easily produce similar examples with the other NPIs, but the examples in (10) should suffice.

${ }^{7}$ All the starred Hindi sentences in this example as well as their English counterparts have a freechoice reading which is well-formed. The stars are meant only for the NPI reading. 


\subsection{Restriction of Universal Quantifiers}

Like the NPIs in English but unlike NPIs in many other languages, NPIs in HIndi are allowed in the restriction of universal quantifiers but not in the nuclear scope, to be suitably contrasted with the existential quantifier which disallows them in both.

(11) a. aisaa har chaatr jisne ek bhii kitaab paRhii, paas ho gayaa such every student who one even book read, passed "Every student who read any book passed"

b. aisaa har chaatr jisne koii bhii kitaab paRhii, paas ho gayaa such every student who any book read, passed "Every student who read any book passed"
c. * aisaa har chatr jo paas huaa kal
kahiiN bhii gayaa such every student who passed yesterday anywhere went
"* Every student who passed went anywhere yesterday"

(12) a. * aisaa koii chaatr jisne ek bhii kitaab paRhii, paas ho gayaa such some student who one even book read, passed

"* Some student who read any book passed"

b. * aisaa koii chaatr jisne koii bhii kitaab paRhii, paas ho gayaa such some student who any book read, passed

"* Some student who read any book passed"
c. * aisaa koii chatr jo paas huaa kal kahiiN bhii gayaa such some student who passed yesterday anywhere went
"* Some student who passed went anywhere yesterday"

The above examples have the more common relative clause as the restriction. Hindi also has another relative-clause-like construction called the participial relative which shows the same distribution:

(13) a. ek bhii kitaab paRhne vaalaa har chatr paas ho jaayegaa one even book reading every student pass will

"Every student who reads even one book will pass"

b. (?) koii bhii kitaab paRhne vaalaa har chatr paas ho jayeega any book reading every student pass will

"Every student who reads any book will pass"

(14) a. * ek bhii kitaab paRhne vaalaa koii chatr paas ho jaayegaa one even book reading some student pass will

"* Some student who reads even one book will pass"

b. * koii bhii kitaab paRhne vaalaa koii chatr paas ho jayeega any book reading some student pass will

"* Some student who reads any book will pass"

\subsection{Correlatives}

A construction-type in Hindi that's related to universals is the correlative construction which consists of a dislocated relative-like clause which can contain multiple occurences of relative ( $w h$-) elements, followed by a main clause with demonstrative pronouns which "match" with the relative pronouns in the preceding clause. As an instance, consider the following sentence: 
(15) jis laRke-ne jis laRkii-ko dekhaa, us laRke-ne us laRkii-ko pasand kiyaa wh boy wh girl saw, that boy that girl liked

As noted in Srivastav (1990), (15) has two interpretations (modulo some nuances):

(16) a. $1<x, y>[\operatorname{boy}(x) \wedge \operatorname{girl}(y) \wedge x$ saw $y][x$ liked $y]$

b. $\forall \mathrm{x} \forall \mathrm{y}[\operatorname{boy}(\mathrm{x}) \wedge \operatorname{girl}(\mathrm{y}) \wedge \mathrm{x}$ saw $\mathrm{y}][\mathrm{x} \text { liked } \mathrm{y}]^{8}$

The fronted relative-like clause is thus a restriction for a definite description or a universal quantifier. Now NPIs are licensed in the first clause (rel) only, but not in the second (dem) clause. Furthermore, NPIs in the first clause disambiguate the sentence, only the universal reading is available:

(17) a. jis laRke-ne jis laRkii-ko kahiiN bhii dekhaa, us laRkee-ne us wh boy wh girl anywhere saw that boy that laRkii-ko pasand kiyaa

girl liked

Only: " $\forall \mathrm{x} \forall \mathrm{y}[$ boy $(\mathrm{x}) \wedge$ girl( $(\mathrm{y}) \wedge \mathrm{x}$ saw $\mathrm{y}$ anywhere][x liked $\mathrm{y}] "$

b. * jis laRke-ne jis laRkii-ko dekhaa, us laRkee-ne us wh boy wh girl saw that boy that

laRkii-ko kahiiN bhii pasand kiyaa

girl anywhere liked

"* Every boy who saw a girl liked her anywhere"

The point to note is that Correlatives, when they are interpreted universally allow NPIs in the restriction of the universal, but not in the nuclear scope.

\subsection{Adversative Predicates}

Hindi NPIs are possible in the complements of some adversative predicates. Examples with $e k b h i i$ 'even one' and zaraa bhii 'even a little' are perfect, examples with koii bhii 'anyone' and kuch bhii 'anything (mass)' are slightly degraded sometimes, but still allowed.

(18) a. mujhe is baat par aaScarya huaa ki ek bhii aadmii tumhaare me this fact on surprise be that one even person your ghar gayaa house went "I am surprised that anyone went to your house"

b. (?) mujhe is baat par aaScarya huaa ki koii bhii tumhaare me this fact on surprise be that anyone your ghar gayaa house went "I am surprised that anyone went to your house"

c. maiN-ne rameS-ko kisii-se bhii baat-ciit kame-se manaa kiyaa/(?)rokaa I Rames anyone talk prohibited/prevented "I prohibited/prevented Rames from talking to anyone" 
d. * maiN-ne kisii-ko bhii rameS-se baat-ciit karne-se manaa kiyaa/rokaa I anyone Rames talk prohibited/prevented "* I prohibited/prevented anyone from talking to Rames"

e. *maiN-ne ek bhii aadmii-ko rameS-se baat-ciit karne-se manaa kiyaa/rokaa I one even man Rames talk prevented

"* I prohibited/prevented even one person from talking to Rames"

f. maiN-ne rameS-ko ek bhii aadmii-se baat-ciit karne-se manaa kiyaa/rokaa I Rames one even man talk prohibited/prevented "I prohibited/prevented Rames from talking to even one person"

It has been noted that in English the verb be glad normally doesn't allow NPIs but that on a special interpretation, viz., what Kadmon and Landman (1993) call the "settle for less" interpretation, NPIs like any are allowed:

(19) a. * John is glad he saw Bill anywhere.

b. John should be glad ANY tickets !

In Hindi, the predicate glad on the interpretation be happy and on the "settle for less interpretation" are expressed by adding different aspectual light verbs to the predicate meaning happy; the former doesn't allow NPIs, the latter does, as the following examples show:

(20) a. * maiN is baat par khuS huuN ki koii bhii mere ghar aayaa I this fact on happy be that anyone my house came "* I am glad that anyone came to my place"

b. tum is baat se khuS raho ki koii bhii tumhaare ghar aayaa you this fact with happy stay that anyone your house came "Be glad that ANYONE came to your place"

\subsection{Before-clauses}

As in English, Hindi NPIs are licensed in indicative and subjunctive (counterfactual) before-clauses but not in after-clauses:

(21) a. kisiike bhii aane-se pahle raam ghar calaa gayaa anyone's coming before Ram home went

"Ram went home before anyone came"

b. is-se pahle ki koi bhii aataa, raam ghar calaa gayaa it before that anyone come-subj., Ram home went

"Ram went home before anyone would come home"

(22) a. * kisiike bhii aane-ke baad raam ghar calaa gayaa anyone's coming after Ram home went

"* Ram went home after anyone came"

\subsection{Yes-No Questions}

A last class of environments where NPIs are found in Hindi is yes-no questions, as one might expect.

(23) a. tumhe koii bhii kitaab pasand aayii kyaa ?

you any book like $Q$


"Did you like any book?"

b. tumhe ek bhii kitaab pasand aayii kyaa? gloss: same as above

c. tumhe kuch bhii pasand aayii kyaa? you anything like "Did you like anything?"

d. tumhe zaraa bhii Saram hai kyaa? you a little even shame be Q "Do you have any shame?"

I will have nothing to say about yes-no questions for the rest of this paper.

\section{NPIs in Generic and Modal Contexts (free choice)}

The espressions being discussed here also behave as "free-choice" items, though the term applied in the context of Hindi is a bit of a misnomer because the relevant interpretation for some of these expressions is not the same as that of the free-choice reading one finds in English, although the free-choice reading is expressed by some of these expressions in generic and modal contexts. The environments in which one finds the "free-choice" reading are: generics, the modals of possibility (in both epistemic and deontic senses) but not of necessity, the future tense at least when used in a generic or modal sense, and also in imperatives. The relevant cases are listed below.

\subsection{Generics}

Hindi NPIs appear freely in generic contexts, as the following examples show. Many of them correspond to the "free-choice" readings one finds in English.

(24) a. koii bhii aadmii is mez-ko uThaa letaa hai any man this table lifts "Any man lifts this table"

b. koii bhii ulluu cuuhoN-kaa Sikaar karta hai any owl mice hunts "Any owl hunts mice"

c. tum to kuch bhii kah dete ho you prt anything say "You say anything" (met. you don't know what to say when)

d. ek bhii cingaarii ghar-ko jalaa detii hai one even spark house burns "Even one spark burns/will burn the house"

e. zaraa bhii zahar khaane-ko bigaaR detii hai a little even poison food spoils "Even a little poison spoils the food"

\subsection{Modals of Possibility}

Hindi NPIs are allowed with modals of possibility (in the deontic, epistemic, and ability senses) but not with modals of necessity, as shown in the following examples: 
(25) a. ek bhii aadmii is mez-ko uThaa saktaa hai one even man this table lift can "Even one person can lift this table"

b. koii bhii aadmii is mez-ko uThaa saktaa hai any man this table lift can "Anyone can lift this table"

c. tum kabhii bhii ghar jaa sakte ho you anytime home go may "You may go home anytime"

d. * kisii-ko bhii ghar jaanaa caahiye anyone home go must

"* Anyone must go home"

e. * ek bhii aadmii-ko ghar jaanaa caahiye one even man home go must "* Even one person must go home"

One must remark at this point that even when modals of possibility are present, NPIs can appear only when the sentences in questions are interpreted generically, crucially, they may not have an episodic reading. Thus when a modal of possibility is interpreted as the modal of ability and the sentence is episodic, the result is degraded:

(26) a. ?? kal raam koii bhii mez uThaa sakaa yesterday Ram any table lift could "?? Yesterday Ram was able to lift any table"

What this shows is the relevant licensing factor even in these cases is really genericity rather than the modal per se.

\subsection{Future Tense}

The future tense allows NPIs to appear when it is interpreted generically, but not when it is interpreted episodically:

(27) a. ek bhii aadmii is mez-ko uThaa legaa one even man this table lift will "Even one person will lift this table"

b. koii bhii aadmii is mez-ko uThaa legaa any man this table lift will "Any person will lift this table"

c. zaraa bhii zahar paanii-ko bigaaR degii a little even poison water spoil will "Even a little water will spoil the water"

d. tum to kuch bhii kah doge you anything say will "You will say anything"

e. ?? kal tiin bajee koii bhii aadmii is mez-ko uThaa legaa tom. 3 o'clock any man this table lift will "?? Anyone will lift this table at 3 o'clock tomorrow"

As before, the crucial feature of these examples seems to be genericity, not the future tense per se. 


\subsection{Imperatives}

As in English, the one non-declarative where free-choice reading of NPIs is found is Imperatives, as the following examples show:

(28) a. kuchh bhii khaa loo

anything eat

"Eat anything"

b. koii bhii seb uThaa loo

any apple pick

"Pick any apple"

The phrases $e k$ bhii 'even one' and zaraa bhii 'even a little' seem odd in the imperative, however:

(29) a. * zaraa bhii khaa lo

a little even eat

"* Eat even a little"

b. * ek bhii seb uThaa lo

one even apple pick

"* Pick even one apple"

I will ignore imperatives for the rest of this paper.

\section{A Unified Analysis of Hindi NPIs and Free-choice NPs: a first approximation}

As in English and as the glosses in the examples cited in sections 4 and 5 show, Hindi NPIs are interpreted as existentials in certain contexts, and as generics (universal-like) in other contexts. The existential interpretation is found in contexts that are "downward-entailing", or DE in Ladusaw's sense (or close enough to being downward-entailing). The generic interpretation is found in generic habitual, modal and future contexts. In other episodic non-DE environments, these expressions are simply disallowed. In this section I provide an account of the distribution of these expressions. The analysis unifies NPI and free-choice interpretations as instances of a more general phenomenon of the way indefinites are interpreted in languages, and the internal composition of these expressions is used to explain the ill-formedness of structures in which these expressions are disallowed.

\subsection{Generic vs. Existential Interpretation of Indefinites}

It has been long observed that in languages like English, indefinite expressions like a man, men, women, etc. can be interpreted existentially or generically depending on the nature of the predicates that they appear as arguments of (Lewis (1975), Kamp (1981), Heim (1982), Carlson (1977), Wilkinson (1986), Diesing $(1990,1992))$. The two kinds of readings are illustrated in the following English sentences:

(30) An owl hunts mice.

Interp. $\mathrm{Gen}_{\mathrm{x}, \mathrm{s}}[\mathrm{x}$ is an owl in situation $\mathrm{s}][\mathrm{x}$ hunts mice in an extension of situation s] 
(31) An owl is hunting mice.

Interp.: $\exists \mathrm{x}[\mathrm{x}$ is an owl $][\mathrm{x}$ is hunting mice $]$.

In English a/an indefinites and bare plurals show the alteration between existentials and generics, but indefinites with some don't. The situation in Hindi is a bit more complicated. Indefinites with koii, kabhii, kuchh, etc. tend to favor an existential interpretation but can be interpreted generically when they are stressed (the most common way of expressing the generic reading in Hindi is the bare singular):

(32) a. koii ulluu cuuhoN-kaa Sikaar kar rahaa hai an owl mice hunt-progressive "An owl is hunting mice"

b. koii ulluu cuuhoN-kaa Sikaar kartaa hai an owl mice hunts

$\exists \mathrm{x}[\mathrm{x}$ is an owl $][\mathrm{x}$ hunts mice $]$

c. KOII ulluu / koii ULLUU cuuhoN-kaa Sikaar kartaa hai (capitals = stress) An owl mice hunts $\operatorname{Gen}_{x, s}[x$ is an owl in s][x hunts mice in an extension of $s]$

I will assume, as has been argued for the English any in Kadmon and Landman (1993) that the NPIs and the free-choice items are the same thing: the existential vs. generic interpretation being just a general property of (some) indefinites, supported by facts independent of Negative Polarity. This existential vs. generic interpretation of indefinites (and the more general quantificational variablity shown by indefinites in the presence of adverbs of quantification) can be accounted for in different ways, for simplicity, I will adopt the popular Kamp/Heim view according to which indefinites are free variables with a restriction that can be bound by a generic operator or adverbs of quantification; the existential interpretation coming about by an operation of Existential Closure that acts on a certain syntactic domain (for one implementation of the exact syntactic conditions under which this operation takes place, see Diesing (1992)). One must bear in mind, however, that this not entirely crucial -- accounts like that of Chierchia (1992) and De Swart (1991), which assume that indefinites are uniformly existential will do as well.

\subsection{Cardinality/Measure Predicates}

I will also assume that indefinites are cardinality predicates (in the count cases) and measure predicates (in the mass cases). This claim has often been put forward on various grounds for indefinites containing determiners like two, three, less than $n$, more than $m$, etc., particularly in connection with there-insertion and also on independent grounds (see e.g., Milsark (1977), Partee (1988), Higginbotham (1987)). I will assume that simple existential indefinites are also cardinality predicates. Thus, the Hindi $e k$ 'one' corresponds to a predicate ONE that is true of anything that contains at least one atomic part. Thus, (33a) can be translated as (33b), which has the same truth conditions as (33c):

(33) a. ek ulluu cuuhoN-kaa Sikaar kar rahaa hai "An owl is hunting mice"

b. $\exists x[O N E(x) \wedge$ owl $(x)][$ be-hunting-mice $(x)]$ 


\section{c. $\exists \mathrm{x}[\mathrm{owl}(\mathrm{x})][$ be-hunting-mice $(\mathrm{x})]$}

Similarly for the mass indefinites, one can assume measure predicates that are isomorphic to the set of positive reals, corresponding to measures of amounts.

\subsection{Association with focus involving bhii}

I will also assume that as in the case of the English even, the Hindi bhii exhibits "association with focus" (cf. Rooth (1985), Krifka (1994)) with the indefinites, the alternatives being other cardinality (or measure) predicates. Thus the alternatives to ONE are TWO, THREE, etc. (I leave the exact syntax of these operations open -- one can assume for example a version of the Karttunen-Peters theory defended in Wilkinson (1993))

\subsection{Indefinite+bhï phrases in Downward-Entailing and Upward-Entailing non-generic contexts}

The assumptions made in sections 6.1-6.3 predict that phrases like $e k$ bhii will be licensed in downward-entailing non-generic contexts but not in upward-entailing non-generic contexts. To see why this is so, consider the simple case of association of bhii mentioned in example (4), repeated here as (34):

(34) RAAM bhii aayaa

$[\text { Ram }]_{F}$ even came

In (34), raam is focussed, and hence the alternatives to it will consist of a set of contextually determined proper names like $\{$ raam, siitaa, mohan, ... $\}$. The proposition asserted by (34) is the proposition that Raam came. The focusinduced alternatives to this proposition are propositions of the form $\{$ that raam came, that siitaa came, that mohan came, ... $\}$. In general, in a structure which exhibits association with focus involving bhii, if the assertion is $a$ and $C$ is the set of the focus induced alternatives to $a$, the following two implicatures result:

(35) a. $\exists \mathrm{p}[\mathrm{C}(\mathrm{p}) \wedge \sim \mathrm{p} \wedge \mathrm{p} \neq \wedge \mathrm{a}]$

b. $\forall \mathrm{p}\left[[\mathrm{C}(\mathrm{p}) \wedge \mathrm{p} \neq \wedge \mathrm{a}] \rightarrow \operatorname{likelihood}(\mathrm{p})>\operatorname{likelihood}\left({ }^{\wedge} \mathrm{a}\right)\right]$

Now consider the sentence (36) which is ill-formed:

(36) * koii bhii aayaa

"* Anyone came"

(36) asserts (37):

(37) $\exists x[\mathrm{ONE}(\mathrm{x}) \wedge \mathrm{x}$ came $]$

(37) corresponds to $a$ in (35), and $C=\left\{{ }^{\wedge} \exists \mathrm{x}[\mathrm{ONE}(\mathrm{x}) \wedge \mathrm{x}\right.$ came $],{ }^{\wedge} \exists \mathrm{x}[\mathrm{TWO}(\mathrm{x}) \wedge \mathrm{x}$ came], ${ }^{\wedge} \exists x[\operatorname{THREE}(\mathrm{x}) \wedge \mathrm{x}$ came]... $\}$. The resulting implicatures are, therefore, as follows:

(38) For some cardinality predicate other than $\mathrm{ONE}$, say $\mathrm{Z}, \exists \mathrm{x}[\mathrm{Z}(\mathrm{x}) \wedge \mathrm{x}$ came $]$. 
(39) For every cardinality predicate other than $\mathrm{ONE}$, say $\mathrm{U}$, if $\exists x[\mathrm{U}(\mathrm{x}) \wedge \mathrm{x}$ came], then likelihood $\left({ }^{\wedge} \exists \mathrm{x}[\mathrm{U}(\mathrm{x}) \wedge \mathrm{x}\right.$ came $\left.]\right)>\operatorname{likelihood}\left({ }^{\wedge} \exists \mathrm{x}[\mathrm{ONE}(\mathrm{x}) \wedge \mathrm{x}\right.$ came $\left.]\right)$.

From (38) and (39) it follows that

(40) likelihood $\left({ }^{\wedge} \exists \mathrm{x}[\mathrm{Z}(\mathrm{x}) \wedge \mathrm{x}\right.$ came $\left.]\right)>\operatorname{likelihood}\left({ }^{\wedge} \exists \mathrm{x}[\mathrm{ONE}(\mathrm{x}) \wedge \mathrm{x}\right.$ came $\left.]\right)$

However given the nature of the alternatives to ONE, it is the case that

(41) $\exists x[Z(x) \wedge x$ came $] \rightarrow \exists x[O N E(x) \wedge x$ came $]$

from which it follows that

(42) likelihood $\left({ }^{\wedge} \exists x[\mathrm{Z}(\mathrm{x}) \wedge \mathrm{x}\right.$ came $\left.]\right) \leq \operatorname{likelihood}\left({ }^{\wedge} \exists \mathrm{x}[\mathrm{ONE}(\mathrm{x}) \wedge \mathrm{x}\right.$ came $\left.]\right)$

which contradicts (40). What this shows is that in upward-entailing contexts like in (36), indefinite $+b h i i$ phrases will always systematically produce contradictory implicatures, leading to the oddity of sentences like (36). This situation however does not obtain in say the scope of negation. To see this consider a sentence like (43), which is well-formed:

(43) koii bhii nahiiN aayaa anyone didn't come "Noone came"

(43) asserts (44) and implicates (45a,b):

(44) $\neg \mathrm{x}[\mathrm{ONE}(\mathrm{x}) \wedge \mathrm{x}$ came $]$

(45) a. For some cardinality predicate other than ONE, say $Z, \neg \exists x[Z(x) \wedge x$ came].

b. For every cardinality predicate other than ONE, say $\mathrm{U}$, if $\neg \exists \mathrm{x}[\mathrm{U}(\mathrm{x}) \wedge \mathrm{x}$ came], then likelihood $\left({ }^{\wedge} \neg \mathrm{x}[\mathrm{U}(\mathrm{x}) \wedge \mathrm{x}\right.$ came $\left.]\right)>\operatorname{likelihood}\left({ }^{\wedge} \neg \mathrm{x}[\mathrm{ONE}(\mathrm{x}) \wedge \mathrm{x}\right.$ came]).

To see that $(45 \mathrm{a}, \mathrm{b})$ are not contradictory note that $(45 \mathrm{a}, \mathrm{b})$ imply that

(46) likelihood $\left({ }^{\wedge} \neg \exists \mathrm{x}[\mathrm{Z}(\mathrm{x}) \wedge \mathrm{x}\right.$ came $\left.]\right)>$ likelihood $\left({ }^{\wedge} \neg \exists \mathrm{x}[\mathrm{ONE}(\mathrm{x}) \wedge \mathrm{x}\right.$ came $\left.]\right)$. and from (41) one obtains (47), by the law of contraposition

(47) $\neg \exists x[\mathrm{ONE}(\mathrm{x}) \wedge \mathrm{x}$ came $] \rightarrow \neg \exists \mathrm{x}[\mathrm{Z}(\mathrm{x}) \wedge \mathrm{x}$ came $]$

and hence (48) follows

(48) likelihood $\left({ }^{\wedge} \neg \mathrm{x}[\mathrm{ONE}(\mathrm{x}) \wedge \mathrm{x}\right.$ came $\left.]\right) \leq \operatorname{likelihood}\left({ }^{\wedge} \neg \exists \mathrm{x}[\mathrm{Z}(\mathrm{x}) \wedge \mathrm{x}\right.$ came $\left.]\right)$.

which does not contradict (47). The above point generalizes to all downwardentailing operators, since if $Q$ is any downward-entailing operator, one can repeat 
the steps shown in (44) through (48), replacing " $\neg$ " with Q, and all the steps go through (because if $\mathrm{Q}$ is $\mathrm{DE}$ it follows from (41) that $\mathrm{Q}\left({ }^{\wedge} \exists \mathrm{x}[\mathrm{ONE}(\mathrm{x}) \wedge \mathrm{x}\right.$ came]) $\rightarrow \mathrm{Q}\left({ }^{\wedge} \exists \mathrm{x}[\mathrm{Z}(\mathrm{x}) \wedge \mathrm{x}\right.$ came $\left.\left.]\right)\right)$. The morphology of indefinite $+b h i i$ phrases combined with the meaning of these items predicts that these phrases will be well-formed in downward-entailing or "negative" contexts but ill-formed in upward-entailing or "positive" contexts.

Before moving to the next section, one remark about a difference between English and Hindi is in order. It is a common observation that in English sentences negation cannot license NPIs in the subject position, unlike many other languages where it is possible (pace certain cases, see Uribe-Etxebarria's contribution to this volume). Thus (49) is ill-formed, in contrast to the Hindi (43):

(49) * Anyone didn't come

Given the discussion in this section, one can produce a reasonable hypothesis as to why this is so. In English, unlike in Hindi, subject indefinites generally don't allow clausemate negation to take wide scope over the existential quantifier. Thus (50a) can be interpreted as (50b) but not (50c):

(50) a. A man didn't come

b. $\exists x[\operatorname{man}(x)][\rightarrow \operatorname{came}(x)]$

c. $\neg \exists \mathrm{x}[\operatorname{man}(\mathrm{x})][\operatorname{came}(\mathrm{x})]$

(50) can be contrasted with (51), where both scopes are possible:

(51) a I didn't see a man
b. $\exists x[\operatorname{man}(x)][\neg \operatorname{see}(I, x)]$
c. $\neg \exists \mathrm{x}[\operatorname{man}(\mathrm{x})][\operatorname{see}(\mathrm{I}, \mathrm{x})]$

(50) moreover is to be contrasted with the Hindi (52) which unlike English allows both scopes:

(52) a. koii aadmii nahiiN aayaa

a man not come

lit. "A man did not come"

b. $\exists x[\operatorname{man}(x)][\neg \operatorname{came}(x)]$

c. $\neg \exists \mathrm{x}[\operatorname{man}(\mathrm{x})][\operatorname{came}(\mathrm{x})]$

In short, given that indefinites in Hindi allow negation to take wide-scope over themselves in the subject position, there is no reason as in English to block NPIs from appearing in the subject position.

\subsection{Indefinite+bhii Phrases in Generic Contexts}

In the last section we saw that the assumption that the meanings of the component parts of Hindi NPIs correctly predict their behavior in non-generic contexts. What about generic contexts? Consider a sentence like (53):

(53) koii bhii aayegaa 
anyone come-FUT

"Anyone will come"

Given what we have assumed about the generic interpretation of indefinites so far, viz., the Kamp/Heim theory and their various offshoots, the assertion corresponding to (53) is something like (54) (where $\mathrm{C}$ is a contextual variable):

(54) $\mathrm{GEN}_{\mathrm{x}, \mathrm{s}}[\mathrm{ONE}(\mathrm{x}) \wedge \mathrm{C}(\mathrm{x}, \mathrm{s})][\mathrm{x}$ will come in some extension of $\mathrm{s}]$

The focus-induced alternatives to this assertions are propositions of the form

(55) ${ }^{\wedge} \mathrm{GEN} \mathrm{x}_{\mathrm{x}, \mathrm{s}}[\mathrm{P}(\mathrm{x}) \wedge \mathrm{C}(\mathrm{x}, \mathrm{s})][\mathrm{x}$ will come in some extension of $\mathrm{s}]$

where $\mathrm{P}=\mathrm{ONE}$, TWO, THREE, etc.

and the implicatures will be the following:

(56) a. For some cardinality predicate other than $\mathrm{ONE}$, say $\mathrm{Z}, \mathrm{GEN}_{\mathrm{x}, \mathrm{s}}[\mathrm{Z}(\mathrm{x}) \wedge$ $\mathrm{C}(\mathrm{x}, \mathrm{s})][\mathrm{x}$ will come in some extension of $\mathrm{s}]$

b. For every cardinality predicate other than $\mathrm{ONE}$, say $\mathrm{U}$, if $\mathrm{GEN}_{\mathrm{x}, \mathrm{s}}[\mathrm{ONE}(\mathrm{x})$

$\wedge \mathrm{C}(\mathrm{x}, \mathrm{s})][\mathrm{x}$ will come in some extension of $\mathrm{s}]$, then likelihood $\left({ }^{\wedge} \mathrm{GEN} \mathrm{N}_{\mathrm{x}, \mathrm{s}}[\mathrm{U}(\mathrm{x}) \wedge\right.$ $\mathrm{C}(\mathrm{x}, \mathrm{s})][\mathrm{x}$ will come in some extension of $\mathrm{s}])>\operatorname{likelihood}\left({ }^{\wedge} \mathrm{GEN}_{\mathrm{x}, \mathrm{s}}[\mathrm{ONE}(\mathrm{x}) \wedge\right.$ $\mathrm{C}(\mathrm{x}, \mathrm{s})][\mathrm{x}$ will come in some extension of $\mathrm{s}])$

One can easily check that the implicatures in (56) are not contradictory. The account developed so far, thus seems to explain (i) the "free-choice" reading of what otherwise are NPIs, and (ii) well-formedness of these expressions despite the lack of downward-entailing operators.

\section{Problems with the above account and a reformulation}

Elegant as the account presented in section 6 is, it also isn't quite right. To see why this is so, note that we assumed that for example koii bhii 'anyone' and $e k$ bhii 'even one' are essentially the same semantically, that is, they are both simple existential cardinality predicates and that the alternatives they introduce are other cardinality predicates. While this assumption does not lead to problems in nongeneric contexts, they do need to be distinguished in the "'free-choice" or generic cases. Compare the two sentences in (57):

(57) a. ek bhii aadmii is mez-ko uThaa saktaa hai one even man this table lift can "Even one person can lift this table"

b. koii bhii aadmii is mez-ko uThaa saktaa hai any man this table lift can "Anyone can lift this table"

While the assertions in (57a) and (57b) are pretty much the same, the implicatures in the two cases are very different. (57a) implicates that the likelihood that some number of people greater than one can lift this table is greater than the likelihood that just one man can lift this table. (57b), by contrast, does not carry any such implicature. There is a certain intuition that cardinality is not as relevant in 
evaluating the implicatures in (57b) as it is in (57a). Furthermore, in generic contexts, koii bhii can appear with numerals, but $e k$ bhii cannot:

(58) a. koii bhii tiin log is mez-ko uThaa sakte haiN

Any three people this table lift can

"Any three people can lift this table"

b. * ek bhii tiin log is mez-kouThaa sakte haiN one even three people this table lift can

"* Even one three people can lift this table"

The contrast between (58a) and (58b) cannot be simply a matter of morphological number clash or anything like that, both koii and $e k$ are morphologically singular, at least in the standard dialects of Hindi (though in some dialects koii can take plural nouns), and the only case of koii cooccurring with a plural $\mathrm{N}^{\prime}$ is when it occurs with numeral phrases.

We can conclude from the above that while phrases like koii and $e k$ are both cardinality predicates, they introduce different alternatives. (similar remarks apply to the pairs zaraa 'little' and kuch 'any (mass)' in the mass indefinites). It is reasonable to assume that whereas the alternatives introduced with $e k$ (and zaraa) are other cardinality (and measure) predicates, the alternatives introduced with koii and kuch are a contextually specified set of properties. To see why this is so, consider the following dialogue between speakers A, B and C modelled on examples in Kadmon and Landman (1993) for Hindi:

(59) A: An owl hunts mice. (ulluu cuuhoN-kaa Sikaar kartaa hai)

B: wrong. A sick owl doesn't hunt mice. (galat. rogii ulluu cuuhoN-kaa

Sikaar nahiiN kartaa)

C: wrong. ANY owl hunts mice. (galat. KOII BHII ulluu cuuhoN-kaa Sikaar kartaa hai)

The dialogue could take place in a situation imagined as follows. Speaker A makes a generic statement, assuming full well that there are principled exceptions, in particular she has in mind old and sick owls. Speaker B assumes that while old owls do indeed hunt mice, sick owls don't. Speaker $C$ assumes that even sick owls don't count as exceptions. Simplifying somewhat, one could assume that the generics taken to be true by the three speakers involve universal quantification where the restrictions to the universal quantifier are of the form $P(x) \wedge$ owl $(x)$, where $P=P_{A}, P_{B}, P_{C}$ for the speakers $A, B$ and $C$ respectively:

(60) $\mathrm{P}_{\mathrm{A}}(\mathrm{x}) \leftrightarrow \neg \operatorname{sick}(\mathrm{x}) \wedge \neg$ old $(\mathrm{x})$

$$
\begin{aligned}
& \mathrm{P}_{\mathrm{B}}(\mathrm{x}) \leftrightarrow \neg \operatorname{sick}(\mathrm{x}) \\
& \mathrm{P}_{\mathrm{C}}(\mathrm{x}) \leftrightarrow \mathrm{ONE}(\mathrm{x})
\end{aligned}
$$

In this situation, the focus-induced alternatives that make C's statement comprehensible are $\mathrm{P}_{A}, \mathrm{P}_{\mathrm{B}}$, and $\mathrm{P}_{\mathrm{C}}$. A universal that has $\mathrm{P}_{\mathrm{C}}$ as it's restriction is the strongest statement and hence it has the least likelihood, and hence the implicatures are satisfied. Furthermore, for any property $\mathrm{P}$ it is the case that

(61) $\forall \mathrm{x}(\mathrm{P}(\mathrm{x}) \rightarrow \mathrm{ONE}(\mathrm{x}))$ 
since ONE is the weakest possible predicate, being true of everything that exists. As one can easily verify, the results of section 6 , viz. the demonstration that association of bhii with focus leads to NPIs being disallowed in upward entailing contexts and allowed in downward entailing contexts does not depend upon the alternatives being TWO, THREE, etc. but will work for any set of alternatives $\left\{\mathrm{P}_{1}, \mathrm{P}_{2}, \mathrm{P}_{3}, \ldots\right\}$, given (61). What gives rise to the behavior of indefinite $+b h i i$ phrases as NPIs and free-choice items in Hindi is the combination of a weak predicate and even, making the structures good in DE contexts and the restriction of generics but not in UE contexts.

Phrases like $e k$-bhii (even one) on the other hand, come with cardinality predicates as their set of alternatives. Thus, replacing KOII BHII with EK BHII in (59C) will sound very odd, even though the assertion would be roughly the same. On the other hand, in a similar dialogue (again modelled after another example in Kadmon and Landman (1993)) between two speakers A and B, where B is a cook who is cooking for 50 people, one must use ek bhii and not koii bhii:

(62) A: Will there be French fries tonight? (aaj french frai hogaa kyaa?)

B: No, I don't have potatoes. (nahiiN, mere paas aaluu (potatoes) nahiiN

A: Not even just a few potatoes that I can fry in my room? (thoRe do-tiin bhii nahiiN jo maiN apne kamre meN tal sakuuN?)

B: Sorry, I don't have any potatoes. (na, mere-paas ek bhii/??koii bhii aaluu

nahiiN)

In this dialogue, speaker B interprets speaker A's denial of the existence of potatoes as a denial of potatoes enough for 50 people, and then asks if he has at least a few (three or two). Speaker B replies by denying the existence of any potatoes in his posession. The point is that the altematives to ONE in this case are cardinality predicates $P_{1}, P_{2}$ and $O N E$, where $P_{1}=$ enough for 50 people and $P_{2}=a$ few. In a situation like this the use of koii instead of $e k$ sounds odd, to say the least: $e k$ bhii is strongly preferred to koii bhii, even though they both deny existence.

In this connection it is also worthwhile to compare the treatment of Hindi NPIs presented here with the account of Kadmon and Landman (1993) for the English any. Kadmon and Landman (1993) derive the distribution of English any by appealing to two properties of any, viz., the requirement that any induces pragmatic widening of the domain of restriction, and the requirement that after pragmatic widening the resultant statement be stronger than without widening. Problems with this approach have been noted, e.g., Krifka (1994) notes cases where the use of any does not induce any pragmatic widening (e.g., in mathematical statements which are very precise and hence pragmatic widening does not arise). The other problem is that the strengthening requirement is a global property of the environments that license any rather than anything about the meaning of any per se. In the present account of Hindi NPIs (which share a lot of properties of the English any), these problems are bypassed. Firstly, pragmatic widening is not required, but since these indefinites are the weakest possible predicates, they are weaker than all their alternatives. Moreover the "strengthening" requirement is a result of the meaning of bhii, which leads to contradictory implicatures in cases where is no strengthening.

\section{Conclusions and Problems for further Research}


In this preliminary report on NPIs in Hindi, I have attempted to show that the meaning of NPIs in Hindi and the reasons for their behavior as NPIs and freechoice elements is predictable from the internal structure of these elements. Some open problems remain, e.g., the fact that $e k$ bhii seems to have a slightly wider distribution than koii bhii, as in the context of adversative predicates. This may well have to do with the syntax of scope of these indefinites ( $e k$ in general allows for wide scope more freely than koii). Details of the syntactic contraints on NPIlicensing is another topic not touched upon here, in particular with respect to mass-indefinites. I'll leave these for further research.

\section{REFERENCES}

Bhatia, T. 1976. Negation in Hindi.. PhD dissertation, University of Illinois at Urbana Champaign, Urbana Champaign.

Carlson, G. 1977. Reference to Kinds in English. PhD dissertation, University of Massachusetts at Amherst, Amherst.

Chierchia, G. 1992. "Anaphora and Dynamic Binding", in Linguistics and Philosophy 15: 111-183.

Diesing, M. 1992. Indefinites. MTT Press, Cambridge.

Heim, I. 1982. The Semantics of Definite and Indefinite Noun Phrases. PhD. dissertation, University of Massachusetts at Amherst, Amherst.

Heim, I. 1984. "A Note on Negative Polarity and Downward Entailingness", in Proceedings of NELS 14, GLSA, Linguistics Dept., University of Massachusetts at Amherst, Amherst.

Higginbotham, J. 1987. "Indefiniteness and Predication", in Reuland, E. and A. ter Meulen (eds.) The Representation of (In)definiteness,, 43-70. MIT Press, Cambridge.

Kadmon, N. and F. Landman. 1993. "Any", in Linguistics and Philosophy 16: 353-422.

Kamp, H. 1981. "A Theory of Truth and Semantic Representation", in J. Groenendijk, T. Janssen, and M. Stokhof (eds.) Formal Methods in the Study of Language, 277-321. Mathematical Centre, Amsterdam.

Krifka, M. 1994. "The Semantics and Pragmatics of Weak and Strong Polarity Items in Assertions", in Proceedings from SALT IV, DMLL, Cornell University, Ithaca.

Lewis, D. 1975. "Adverbs of Quantification", in Keenan, E. (ed.) Formal Semantics of Natural Language, 3-15. Cambridge University Press, Cambridge.

Milsark, G. 1977. "Toward an Explanation of Certain Peculiarities in the Existential Construction in English", Linguistic Analysis 3, 1-30.

Partee, B. 1988. "Many Quantifiers", in Proceedings of ESCOL 5, 383-402, DMLL, Cornell University, Ithaca.

Rooth, M. 1985. Association with Focus. PhD. dissertation, University of Massachusetts at Amherst, Amherst.

Swart, H. de 1991. Adverbs of Quantification: A Generalised Quantifier Approach. PhD. Dissertation, Rijksuniversiteit Groningen, Groningen.

Uribe-Etxebarria, M. 1995. "Negative Polarity Licensing, Indefinites, and Complex Predicates", this volume.

Wilkinson, K. 1986. "Generic Indefinite NPs", ms., University of Massachusetts at Amherst, Amherst. 